\title{
First- and second-order global sequence stratigraphic correlations and accommodation charts for the Kaapvaal, Karelian, São Francisco (-Congo) and Slave cratons: an introduction
}

\author{
P.G. Eriksson ${ }^{\mathrm{a}^{*}}$, O. Catuneanu ${ }^{\mathrm{b}}$ and A.J. Bumby ${ }^{\mathrm{a}}$ \\ ${ }^{a}$ Department of Geology, University of Pretoria, Pretoria 0002, South Africa; * corresponding \\ author,e-mail: pat.eriksson@up.ac.za \\ ${ }^{b}$ Department of Earth and Atmospheric Sciences, 1-26 Earth Sciences Building, University of \\ Alberta, Edmonton, Alberta T6G 2E3, Canada
}

\begin{abstract}
This set of papers provides a pilot study of global sequence stratigraphic correlation for the Precambrian for five chosen cratons. Detailed chronostratigraphic charts summarize the supracrustal geological evolution of each craton, and are in the form of adapted Wheeler diagrams to enable estimation of first- and secondorder sequence stratigraphy for the cratons. Thus, the manuscripts examine evidence within the Precambrian sedimentary record for events of apparent global significance, across several preserved Precambrian cratons, utilising chronological data, inferred geodynamic and basin evolutionary histories, palaeosols, erosional hiatuses, and interpreted chemical, biochemical, palaeobiological, palaeoatmospheric and palaeoclimatic changes. The adapted Wheeler diagrams attempt to reflect time within hiatuses as well as within depositional sequences, in accord with the distinctly punctuated nature of the global stratigraphic record. The supercontinent cycle is examined for its antiquity and its application to Precambrian cratons, and a commentary is given on an emerging "conventional view" of the Precambrian wherein supercontinentality is seen as a global phenomenon by the Neoarchaean already (or alternatively only by ca. $2.0 \mathrm{Ga}$ ), on the nature of the "Great Oxidation Event" at ca. 2.4-2.3 Ga and possibly concomitant widespread glacial events at approximately the same time period. It is hoped that the present pilot study will stimulate an examination of accommodation changes over time for all ancient cratons, thus enabling a more comprehensive assessment of global correlations and high-order (first- and second-order) accommodation changes. This might lead to an improved appreciation of the inherent complexity of the individual facets making up the currently developing "conventional view" of Precambrian geological evolution.
\end{abstract}

Keywords: Precambrian; sequence stratigraphy; supercontinents; "Great Oxidation Event"; glaciation; accommodation charts; Kaapvaal, São Francisco, Congo, Karelian and Slave cratons

\section{Introduction}

This set of papers examines global correlations for the Precambrian time period for a group of Precambrian cratons from across the globe, based on detailed chronostratigraphic charts (summarizing the supracrustal geological evolution of each craton) shown as adapted Wheeler diagrams for individual sedimentary basin-fill successions, with the aim of establishing first- and second-order sequence stratigraphy for the chosen set of cratons. The ultimate aim of the project was to attempt a pilot study of global sequence stratigraphic correlation; this has not been done before at this scale. The 
separation of first-order sequences is related to specific tectonic settings in the evolution of a chosen craton, with the first-order sequence boundaries marking changes in the tectonic setting, while the subdivision of first-order sequences into Sloss-scale secondorder sequences is at regional group and supergroup level. A set of four introductory papers examines major issues encompassed in such global correlation attempts, followed by the body of the collection of papers, which consists of four specific craton casestudies.

Earth evolution, in the Precambrian and later, essentially involves the interaction of a complex set of geological controls, viz. mantle thermal processes, plate tectonics, sedimentation systems, palaeobiological evolution, palaeoatmospheric and palaeoclimatic changes, which together produced the extant rock record (e.g., Eriksson et al., 2004 and references therein). The aim of this set of manuscripts is to examine evidence within the Precambrian sedimentary record for events (of whatever genetic origin) that appear to be of global significance, rather than craton-specific or even more localised occurrences. To this end, correlations across several preserved Precambrian cratons are deemed significant, particularly as regards chronological data, interpreted geodynamic and basin evolutionary histories, palaeosols, erosional hiatuses, as well as chemical, biochemical, palaeobiological, palaeoatmospheric and inferred palaeoclimatic trends and changes.

The key element provided here is the chronostratigraphic charts, which are envisaged as adapted Wheeler diagrams, where the essential element is the time control; this implies attempting to establish how much time is in hiatuses versus depositional sequences - at least for the major stages of craton evolution, depending on the resolution that can be resolved for the chosen case studies. From this basis, accommodation changes can be inferred. The reason that accommodation charts are utilised, rather than sea-level, relative sea level, or subsidence curves, is because accommodation is the combination of all allogenic controls, and this avoids the very difficult inferences of how much of that space can be attributed to eustasy, or subsidence, etc. In addition, accommodation defines the space available for sediments to accumulate in both underfilled and overfilled sedimentary basins, and hence in any depositional setting, whether or not influenced by sea-level fluctuations (for a full exposition of these factors, see for example, Catuneanu, 2006). For each case study a discussion of the likely controls on accommodation is provided.

\section{A "conventional viewpoint" framework for stratigraphic studies of the Precambrian time period?}

There are many challenges for the Precambrian sedimentologist and stratigrapher, which are not experienced when working in the Phanerozoic and younger rock record. In the Phanerozoic, time control is of high quality, based not just on accurate radiometric dating but also on a reasonably complete, invertebrate and vertebrate fossil record. The succession of Wilson cycles and the interaction of mantle-thermal processes with the well defined plate tectonic regime in their genesis are well established; supercontinent reconstructions can be made with some confidence, and mobile belts, palaeoclimatic changes and palaeoatmospheric variability are reasonably well quantifiable.

Little of this predictable framework for sedimentological - sequence stratigraphic studies can be relied upon in a Precambrian context. The onset of Phanerozoic-Modern 
type plate tectonics, the nature of mantle-thermal processes and the importance and occurrence of mantle plumes and superplumes are as yet incompletely resolved (e.g., Eriksson et al., 2004 and references therein for an overview of many of the debated issues). While some argue for a "normal" plate tectonic regime deep into Archaean time (e.g., de Wit et al, 1992; de Wit and Hynes, 1995; de Wit and Ashwal, 1997; de Wit, 1998), others discount this and postulate that such a regime was only pertinent much later in the Precambrian (e.g., Hamilton, 1998); perhaps, a more reasonable approach is to discuss a gradational change from a mantle-dominated Earth to one where rigid plates and their migration slowly became predominant (Trendall, 2002), but debate on the timing of such a transition remains contentious (e.g., Eriksson and Catuneanu, 2004).

However, despite still-open debate on these issues (and many other unresolved Precambrian Earth evolution questions), there is also a widely held "conventional opinion" which constitutes a relatively fixed framework for the Precambrian, as discussed later in this section. A pertinent example of the apparent contradiction between highly divergent views and a possible "conventional view", is provided by opinions on the Precambrian expression of the supercontinent cycle (e.g., Unrug, 1992; Rogers and Santosh, 2002), a concept implicit within studies of Phanerozoic sequence stratigraphy and one also related to postulated palaeoclimatic variation and biological evolution on the planet across the time scale (e.g., Aspler and Chiarenzelli, 1998). A rather confusing plethora of suggested supercontinental assemblies is to be found in the literature, including, for example: (1) ca. 3.0 Ga "Ur" (core of Indian cratons, with Kalahari, Western Dronning Maud, Napier, Pilbara); (2) ca. 2.5 Ga "Arctica" (Aldan, Anabar/Angara, Slave, Rae, Greenland, Hearne, Nain, Superior, Wyoming cratons); (3) ca. 2.0 Ga "Atlantica" (West Africa, Congo/Kasai, Guyana, Brazil, São Francisco, Rio de la Plata); (4) ca. >1.5 Ga "expanded Ur" (with addition of Zimbabwe, Madagascar, Bundelkhand, Aravalli, Yilgarn, Kimberley, Gawler cratons, Eastern Australian terranes); (5) ca. $1.5 \mathrm{Ga}$ "Nena" (addition of Baltica and most of East Antarctica to "Arctica") (see Rogers, 1996; Ruban, 2007). Many of the reconstructions of cratonic amalgamations rest on palaeomagnetic data, yet such data older than ca. $1.8 \mathrm{Ga}$ are commonly considered unreliable; e.g., the palaeomagnetic data used to support the inferred ca. 1.9-1.5 Ga "Columbia" continent (Rogers and Santosh, 2002) is considered to be questionable (Meert, 2002). For $>1.8 \mathrm{Ga}$ reconstructions, thus, recourse must needs be had to geological data such as geochronology or matching of major structural features such as mobile belts (Meert, 2002).

Another proposed early Precambrian supercontinent, the Neoarchaean "Kenorland" (Williams et al., 1991), is well supported by a large geochronological database and has since been expanded to include the Baltic and Siberian shields in addition to the original assembly of the cratons of North America (Aspler and Chiarenzelli, 1998). In view of the evidence in favour of this amalgamation, which also extends to generally easily correlatable supracratonic sedimentary-volcanic successions (e.g., Ojakangas et al., 2001), Kenorland has tended to become relatively well established in literature and to have assumed something of a mantle of "convention", supporting not just this specific example of a supercontinent, but also the broad concept of supercontinentality per se as a global state in the Neoarchaean (see discussion in Eriksson et al., 2009; 2011a). Within this framework of inference, a "southern equivalent" of Kenorland has also enjoyed wide support (e.g., de Kock et al., 2009, most recently), known variously as "Vaalbara" 
(Kaapvaal and Pilbara cratons; Cheney, 1996) or the expanded "Zimvaalbara" (Zimbabwe craton added; Stanistreet, 1993). For the latter postulated supercontinent, a common Neoarchaean-Palaeoproterozoic set of successor and distinctly coeval basins is suggested (e.g., Cheney, 1996; de Kock et al., 2009 and several others in between). For Kenorland, an analogous view has become well entrenched in literature, of correlated Palaeoproterozoic supergroups from the Superior (Huronian), Wyoming (Snowy Pass) and Fennoscandian (Karelian supergroups) cratons (e.g., Ojakangas et al., 2001). The suggested "convention" that is becoming an established point of view thus encompasses widespread supracrustal sedimentary-volcanic successions which occur across large swathes of apparently amalgamated cratonic plates in a set of essentially coeval basins, wherein individual sets of strata, reflecting specific interpreted tectonic and depositional origins (e.g., glacial; cf. Ojakangas et al., 2001; Young, 2004; and references therein), can be matched from basin to basin and are accepted as being chronological and palaeoenvironmental markers.

Ironically, despite the Phanerozoic being seen by many as a suitable genetic guide to Precambrian evolution (e.g., for tectonic regimes, basin-fills, and even arc complexes/greenstone belts - e.g., de Wit and Ashwal, 1997) this does not seem to apply to internal complexities within the Phanerozoic supercontinental sedimentary record, which is well studied, well dated and much better preserved than Precambrian basin sets; a pertinent example would be the very widespread Karoo basins of supercontinent Gondwana. Examining only those Karoo basins currently preserved on a single continent from Gondwana, namely Africa, in excess of 50 individual Karoo-type basins (Carboniferous - Jurassic) are known; a southern group of basins dominated by the Main Karoo basin of South Africa comprises depositories related to a flexural retro-arc tectonic setting, and this contrasts with essentially rifted (extensional or transtensional rifting) basins further north (e.g., Catuneanu et al., 2005). While palaeoclimatic change related to plate tectonic movement of Gondwana across a spectrum of palaeolatitudes varying from polar to temperate desert settings, resulted in broadly analogous Karoo successions being preserved in most Karoo basins, not just in Africa but across Gondwana, the ages of the different palaeoenvironmentally controlled subdivisions changes across the preserved daughter fragments of Gondwana. Cesari et al. (2011) suggest an age difference of ca. 25-48 My between South American and Southern African basin-fills. For the Karoo basin-fills thus, any assumption of common broad tectonic setting does not appear fully justifiable, nor can the assumption of chronological comparability of sets of beds ascribed to a particular environment (i.e., glacial deposits of "Dwyka" affinity, or desert deposits of "Clarens" affinity, to use well known Main Karoo basin stratigraphic terminology) be made with any great confidence. The widely accepted paradigm for early Precambrian supracratonic correlation implicit in the "convention" alluded to above must thus be questioned on the basis of the Phanerozoic record. This is part of the motivation for this set of papers and its emphasis on accommodation charts which encompass preserved sedimentary and volcanic deposits, hiatuses, known geochronology, inferred depositional as well as mantle-thermal and tectonic settings.

We stress an additional caveat when studying the Precambrian sedimentary record and postulated correlations across extant cratons, namely the nature of the stratigraphic rock record (at all ages). It is now thirty years since Ager (1981) published the widely read second edition of his book on the nature of the Earth's stratigraphic record, yet the 
veracity of his basic homily, that the gaps in this record are far greater than the record itself, still pertains. Determining the relative proportions of hiatuses and preserved record is a complex task, intimately related to sedimentation processes, erosion at a multitude of time scales, sedimentation rates, tectonic regime, and eustasy amongst others (e.g., Miall, 1997, his chapter 12). Miall (1997) further emphasizes that the time scale itself is inferred to be hierarchically cyclical in nature. It is a basic fact that the longer the time interval examined, the greater will become the cumulative effect of hiatuses reflecting either nondeposition or erosive removal, due to the increase in both the number and the length of the breaks in the preserved record (Miall, 1997). In parallel with this observation, the preserved record also decreases as sedimentation rate decreases (Crowley, 1984). In view of these facts, it is surprising that so much effort by many scientists is invested into correlations of supracrustal successions across modern craton boundaries - when some of the preserved sedimentary successions might match up, at least in the view of the person concerned, there appears to be little concern over never being able to accurately match up the length and frequency of the hiatuses themselves, that might in fact outweigh the record we see. In the same vein, the only chronology directly applicable to sedimentary basin-fills is that of detrital zircons, where the time trends of different-aged zircon populations are used as a basis for chronological discrimination and comparison; comparison of such trends emphasizing the "gaps" in the detrital zircon record are often tied to inferred tectonic history of the basinal successions being examined, with little thought to the nature of the record overall and its necessary skewing of any part of the detrital preservation, which is often largely "accidental" (cf., Miall, 1997 and references therein). This is a further reason for adopting accommodation charts in this set of papers, for attempts at large scale or even global correlations of cratonic supracrustal records.

Building further on the discussion above, there appears to be a widely acknowledged "conventional acceptance" for a specific chronological and Earth-evolutionary framework for the Archaean-Palaeoproterozoic (e.g., discussion in Eriksson et al., 2011b):

(1) One relatively well defined ("Kenorland") Neoarchaean supercontinent, with possibly one other, poorly constrained "southern" equivalent (cf. "Vaalbara", "Zimvaalbara" etc.) (e.g., Aspler and Chiarenzelli, 1998); a similar viewpoint of multiple, yet independent "supercratons" by the Neoarchaean but with distinct histories of formation and dispersal (e.g., Bleeker, 2003).

(2) A reducing palaeo-atmosphere and -hydrosphere before ca. $2.4 \mathrm{Ga}$, followed by the "Great Oxidation Event" (GOE), with views on the timing of the latter varying somewhat (between, ca. 2.3 and 1.8 Ga; Holland, 1964, 1966, 1984, 1994, 2002; Cloud, 1968, 1973; Walker, 1977; Walker et al., 1983; Kasting, 1987, 2001; Kasting and Brown, 1998; Rye and Holland, 1998; Kasting and Siefert, 2002; Huston and Logan, 2004; Farquhar et al., 2010; Leach et al., 2010). The "conventional" view would place the GOE at ca. 2.35-2.3 Ga; however, the doyen of such studies, Holland (2009) in a recent paper did not place it any more specifically than having been between 2.4 and $2.3 \mathrm{Ga}$.

(3) Widespread to planetary scale glacial events in the ca. 2.4-2.2 Ga time period, with up to three known glacial horizons identified in North America, and these glacial deposits are commonly seen as being related to the "Snowball Earth 
hypothesis" (e.g., Kirschvink, 1992; Hoffman et al., 1998) or its subsequent guise of "Slushball Earth", necessitated due to significant conflicting data (e.g., Young, 2004).

(4) Formation of large supercontinent(s) (cf. Laurentia) by ca. 2.0 Ga (e.g., Hoffman, 1988) as a global phenomenon.

While not wishing in any way to lessen the important contributions of a large number of scientists over many years, particularly related to supporting the perceived "convention" outlined above, it is a fact of human nature, within all things and especially within science, to seek for a simple structure and framework upon which to base our alas incomplete comprehension of the natural world. In this short paper, we are merely arguing in favour of a more complex nature to early Earth-evolution, wherein diachronous relationships and gradual changes taking place at different rates and intensities (cf. Donaldson et al., 2002) on different preserved Archaean cratons, has given us a rock record which is distinctly challenging to research, and not necessarily that amenable to simple interpretations.

While evidence for a "Kenorland" amalgamation is strong, the same cannot be said for the so-called "southern" cratons (e.g., discussion in Eriksson et al., 2009, 2011a). In the same way that certain cratons (e.g., Kaapvaal) stabilised earlier than others, thereby accommodating large basins (cf., ca. 3.1-2.8 Ga Witwatersrand basin on Kaapvaal) of greater antiquity than on other cratonic blocks, we suggest that supercontinents likely followed a similar evolutionary path, with "Kenorland" perhaps being the first, although this will be disputed by many (see references above on supercontinents) and is also supported by some views in the individual papers in this thematic set; only later (ca. 2.0 $\mathrm{Ga}$ ?; further discussion below) did supercontinentality per se become a pervasive framework of stratigraphic evolution on Earth. We plea thus for open debate and acceptance of a likely much more complex Earth history in preference to the perceived "conventional view".

Analogously, the "Great Oxidation Event" (GOE) appears to be a good deal more complex than a simple event in a fixed framework. Isotopes used as oxygen proxies to estimate palaeoatmospheric and -oceanic chemistry reveal conflicting trends: Neoarchaean Mo isotopic values from black shales (from the Transvaal Supergroup, Kaapvaal) exhibit rapid fluctuation over the ca. 2.64-2.5 Ga period implying rapid change from oxygen-free oceans to cyanobacterial production of oxygen in the oceans (Voegelin et al., 2010); Mo isotopes from carbonate rocks from the same geological interval exhibit a constancy suggesting near-continuous oxygen presence, which Voegelin et al. (2010) ascribe to detrital inputs and concomitant dilution effects related to palaeoenvironmental influences. $\mathrm{Cr}$ isotopes from banded iron formations support a transient rise in palaeoatmospheric oxygen at $\sim 2.8-2.6 \mathrm{Ga}$, before the GOE, and decline thereafter to pre-GOE levels, thereby suggesting that the GOE might possibly have been a passing event rather than the first in a step-wise increase in global redox (Frei et al., 2009).

Turning to point \#3 above, the very origin of glacigenic horizons in the Palaeo- and Neoproterozoic records is still poorly understood, and there is a significant body of data that appears to negate the "Snowball/Slushball Earth" scenario (cf., Young, 2004; Williams, 2004 for two recent overviews). In contrast, few would dispute point \#4 above, 
that supercontinentality had become an established and pervasive influence in global tectonic evolution by about $2.0 \mathrm{Ga}$; the implication of this is to underline that supercontinentality may have begun in the Neoproterozoic, but not universally so for all then-extant cratons. Condie et al. (2009) summarise data supportive of a global magmatic shutdown in the ca. 2.45-2.2 Ga time period, and it is possible that this might provide a more plausible explanation of a potentially transient GOE and the first widespread glaciation at ca. 2.4-2.2 Ga. We stress again here the well known incomplete nature of Earth's stratigraphic rock record and the concomitant danger of over-interpretations of global isotopic curves as reflecting change in palaeoatmospheric/-oceanic compositions and the waxing and waning of ice ages and their non-glacial interregnums. It is for all these reasons that we chose to make an attempt at setting up provisional global accommodation charts for major basins preserved in the Precambrian supracrustal rock record, so as to provide a reasonably precise data base for further debate on what are in reality very complex issues within a fascinating science.

\section{Introductory papers}

In the first introductory paper, P.G. Eriksson, O. Catuneanu, D.R. Nelson, M.J. Rigby, P.C. Bandopadhyay and W. Altermann provide a more in-depth discussion of many of the issues raised above, through a critical analysis of the "events" used for largescale correlation attempts across the currently widely dispersed Precambrian cratons on the planet. They find that most of these events, supercontinent, mantle plume, orogenic, chemostratigraphic and glacial, as well as major unconformities, relate essentially to the first-order interaction of mantle thermal and plate tectonic processes on Earth, with impact events (cf., spherule beds) being the exception. These same tectono-thermal events are those ascribed as controlling the chronologically compatible first- and secondorder sequence stratigraphic cycles; again, this is a primary reason for the application of sequence stratigraphy at these orders in this thematic paper set. They offer the added advantage of encompassing hiatuses in deposition (as far as they will ever be known or determinable) and they also implicitly include the interaction of global change in sea level with local tectonic effects on accommodation.

The second paper (O. Catuneanu, M.A. Martins-Neto and P.G. Eriksson) explores the basic tenets of sequence stratigraphy (cf., Catuneanu, 2006; Catuneanu et al., 2009), underlining the observation of stratal stacking patterns in the rock record, which can be interpreted in terms of specific genetic types (forced regressive, lowstand normal regressive, transgressive, and highstand normal regressive) of deposits, bounded by sequence stratigraphic surfaces, within a basin-fill. Different scales of observation allow assignment of sequences and sequence stratigraphic surfaces within a set of hierarchical orders. The concept of accommodation (cf., space available to be filled by sediment), which is a major theme in this collection of papers, is central in sequence stratigraphy. The specific application of sequence stratigraphy to the Precambrian rock record is discussed.

In the third paper (P.K. Bose, P.G. Eriksson, S. Sarkar, D.T. Wright, P. Samanta, S. Mukhopadhyay, S. Mandal, S. Banerjee and W. Altermann) a brief exposition of the possibly unique aspects of Precambrian sedimentation regimes is provided, stressing the importance of variable rates and intensities of genetic processes in contrast to the 
uniformity of processes themselves, their products and controls on deposition (cf. Donaldson et al., 2002). While deltaic, aeolian, glacial and lacustrine deposits are thought to have been largely analogous to Phanerozoic equivalents, their first-order geodynamic controls are inferred to have been subject to unique characteristics. They stress that the epeiric basins commonly preserved on many cratons provide a poor means for elucidation of sedimentation within the Precambrian marine realm, and note the role of microbial mats in preservation of sediment stacking and architectural patterns, something that will not apply readily to Phanerozoic equivalents. The evolution of biota over Precambrian time greatly affected carbonate sedimentation patterns. Poor soils and a lack of vegetation skewed channel systems (alluvial, deltaic, tidal) towards braided patterns, and temporary ponding of muddy detritus likely raised palaeoslopes locally, thereby preserving evidence for unusual palaeohydraulic parameters compared to younger equivalent alluvial deposits.

In the final introductory paper, (K.O. Strand) major glaciations in the Precambrian are examined, and the merits of the "Snowball Earth" hypothesis and alternative models are weighed. Strand underlines the genetic importance of tectonic control (especially rifting, subsequent thermal subsidence, and a relationship to continental breakups) in consort with palaeo-atmospheric changes. Perhaps most importantly, he stresses the critical need to carry out detailed studies of the sedimentary history and sequence stratigraphy of not only the glacigenic deposits themselves, but also immediately preglacial and post-glacial beds as well. While emphasizing the importance of rifting and rift-related uplift in possibly generating glacial deposits of a relatively localised scale, Strand also stresses the occurrence of widespread ice sheets on passive continental margins. He finds that genesis of Precambrian glacial deposits is likely more complex and multi-faceted than the rather simple yet elegant tenets of the Snowball Earth model.

\section{Craton-specific papers}

In the first of these papers, P.L. Corcoran reviews the geodynamic evolution of the Slave craton, with emphasis on the sedimentary-volcanic record preserved on the Central Slave superterrane. Here, ca. 4.03-2.93 Ga basement lithologies are unconformably succeeded by a succession of relatively widespread quartz-arenitic rocks (with subordinate BIF, mafic and felsic volcanics) of the ca. 2948-2826 Ma Central Slave Cover Group which are ascribed to a rifted, possibly estuarine continental margin setting. The "basal unconformity" is complicated by deformation at that level as well as an overlap in chronology of both basement and supra-crustal rocks, and a major drowning event (ca. 3.0-2.9 Ga) surmised at this level has been related by some authors to breakup of a possible Mesoarchaean continent. This would of course have preceded "Kenorland" discussed previously, and immediately opens the debate on the antiquity of an early, possibly primitive version of the supercontinental (cf., Wilson also?) cycle. However, comparison with another craton studied here (Kaapvaal, below) is instructive in analysing the global universality of such a possibility. A considerable hiatus (concomitant with regional deformation and uplift) followed on Slave, and was succeeded by the ca. 2722 2603 Ma Yellowknife Supergroup (essentially greenstones), comprising widespread basal mafic volcanics ascribed to seamounts, more lenticular succeeding felsic volcanics and two generations of deep marine turbidite deposits; an overall compressive tectonic setting is envisaged with fore-arc, intra-arc and back-arc rifting inferred and a terrane 
amalgamation scenario interpreted. Uppermost ca. $<2.6 \mathrm{Ga}$ conglomeratic alluvial-shelf deposits complete the Slave succession studied, and ca. 2630-2580 Ma granitic plutons signalled final cratonisation of the Slave terranes.

An interesting comparison to the Slave paper is provided by that on the Kaapvaal craton (A.J. Bumby, P.G. Eriksson, O. Catuneanu, D.R. Nelson and M.J. Rigby), where accommodation curves are provided for a successor basin series comprising the ca. 3.1-2.8 Ga Witwatersrand-Pongola depository, the ca. 2.7 Ga Ventersdorp basin, three preserved ca. 2.66-2.1 Ga Transvaal sub-basins, and the two ca. 2.06-1.7 Ga Waterberg depositories. While there is no evidence for a Mesoarchaean continent in the case of the Kaapvaal craton, it became stable and was able to undergo shortening to form the oldest large basin on Earth (Witwatersrand) ca. 500 My before cratonisation was complete for the Slave craton. Granite plutonism (related to complete cratonisation) overlapped with Witwatersrand sedimentation and likely affected sediment provenance. The Witwatersrand accommodation was dominated by foreland system flexural subsidence, with the Witwatersrand Supergroup being deposited in the foredeep and the partly coeval Pongola Supergroup in the back-bulge basin. While the widespread quartzitic arenites of Slave (ca. 2948-2826 Ma) are comparable as a gross lithology to the famous auriferous conglomerates and sandstones of the upper Witwatersrand succession (cf., Central Rand Group), the inferred tectonic settings are greatly different, extensional for Slave and compressional for Kaapvaal. Both Slave and Kaapvaal appear to have undergone significant deformation, uplift and a depositional hiatus in the ca. 2.8-2.7 Ga period. On Kaapvaal, the ca. 2714-2709 Ma (-2.66 Ga?) Ventersdorp Supergroup basin-fill was accommodated largely by rifting and thermal influences related to a mantle superplume; at the same approximate time, Slave was characterised by the Yellowknife greenstones formed within a presumed amalgamation setting.

The uppermost Ventersdorp rift-related sedimentary-volcanic deposits may have been comparable to basal rift-related small proto-basins within the Transvaal Supergroup. This unit comprises subsequent thick chemical sedimentary platform deposits (ca. 2585-2432 $\mathrm{Ma}$ ) in its basal half, followed by clastic and volcanic units in its upper part; overall a thermally influenced sag basin setting is envisaged for the predominant epeiric marine style of sedimentation, with inferred global eustatic highs related to a continental growth maximum close to the Archaean-Proterozoic boundary also thought to have been an important influence on accommodation, particularly for the chemical sedimentary platform deposits. Two glacigenic horizons are preserved on Kaapvaal. Proterozoic sedimentary depositories on this craton terminated with the two Waterberg sub-basins, whose accommodation is related to both Bushveld Complex intrusion (ca. $2058 \mathrm{Ma}$ ) and assembly of the inferred Eburnean African supercontinent (ca. 2.2-1.8 Ga).

The final two papers in the thematic set, by K.O. Strand on the Karelian craton, and by F.F. Alkmim and M.A. Martins-Neto on the São Francisco craton, enable comparisons with each other and with Kaapvaal, to address possible discrimination of global events versus craton-specific events, and also to explore cross-craton correlations, as will be detailed below. For the São Francisco craton, a passive margin setting along the Archaean nuclei of both the São Francisco and Congo cratons between ca. 2.5 and 2.1 $\mathrm{Ga}$ is inferred, with development of the lower second-order sequence identified in the Minas-Itacolomi succession on São Francisco; the upper second-order sequence of this succession in São Francisco is related to the ca. 2.1 Ga collision of this craton with the 
Congo craton, seen by the authors as part of the assembly of supercontinent "Atlantica". For the Kaapvaal craton, the Transvaal Supergroup can be divided into two first-order sequences (ca. 2.58 - 2.4 Ga chemical sedimentary platform of the Chuniespoort-GhaapTaupone Groups; ca. 2.3 - 2.1 Ga clastic-volcanic succession of the Pretoria Group and equivalents); the second is further subdivided into two second-order rift-thermal subsidence sequences during which major epeiric basins developed on the Kaapvaal craton, which are comparable to the inferred passive margin deposit on São Francisco at ca. $2.5-2.1 \mathrm{Ga}$. For both these cratons, a major drowning event and geodynamic resurgence are recorded at ca. $2.2-2.1 \mathrm{Ga}$. When Kaapvaal and São Francisco are compared to the Karelian craton, a different scenario is seen, with ca. 2.4->2.25 Ga riftrelated deposits which are interpreted as having been transitional to a passive margin setting preserved on the latter. The ca. 2.25-2.1 Ga East Puolanka Group on Karelia reflects a passive margin prism and subsequent sea level drop, again in contrast to what is observed on Kaapvaal and São Francisco. We suggest that the differences between the Karelian craton and the other two likely reflects the former having probably formed part of the postulated "Kenorland" supercontinent, while both Kaapvaal and São Francisco probably were not part of any amalgamation until the major ca. 2.2-1.8 Ga global assembly event.

With the ca. 2.06 - 1.7 Ga Waterberg basin of Kaapvaal reflecting craton-wide stresses related to both Bushveld Complex plume impingement and the Eburnean supercontinent (ca. 2.2-1.8 Ga) assembly, Precambrian supracrustal deposition on that craton effectively came to an end. On São Francisco, the combined plate of this craton with Congo, underwent rifting at ca. $1.75 \mathrm{Ga}$ and the resultant basins accommodated the Espinhaço I sequences; renewed rifting at ca. $1.57 \mathrm{Ga}$ led to reactivation and the lower part of the Espinhaço II sequence, followed by sag basin development, major marine incursions and the Upper Espinhaço II sequence. With breakup of the Rodinia supercontinent which had included São Francisco-Congo, initial bimodal volcanism on both cratons was followed by rifting in the former craton which accommodated deposition of the Macaúbas first-order sequence, followed in time by the first-order Bambui sequence on São Francisco in the Ediacaran period with formation of the Gondwana supercontinent.

\section{Conclusions}

The thematic set of papers reflects a first-pass or pilot study of only five early Precambrian cratons and their supracrustal first- and second-order sequences, illustrated through detailed chronostratigraphic charts modelled on Wheeler diagrams. As such we hope that this will lead in the longer term to a much more complete analogous data base for accommodation changes over time for Earth's preserved ancient cratons, so that a much more comprehensive assessment of global correlations and high-order (cf., firstand second-order sequences; cf., Catuneanu, 2006) accommodation changes can be made. This will enable a much greater understanding and appreciation of the complexity of facets of the "conventional view" perceived to exist in much of the global literature.

From this initial study we can already postulate the following major conclusions: 
(1) Craton development early in Earth history appears to have been unique for each craton, with smaller plate amalgamations having possibly been pertinent in a few cases, as shown from a comparison of the accommodation and geohistory ( $\geq$ Neoarchaean in age) summaries provided for the Slave and Kaapvaal cratons.

(2) While support for one (cf., "Kenorland") or only a relatively small number of Neoarchaean cratonic assemblies appears good, this concept should not be accepted as a universal truth of global scale (cf. the "panacea" viewpoint discussed by Eriksson et al., 2011b); the onset of supercontinentality across the globe should rather be seen as an essentially diachronous event that only became pervasive by ca. $2.0 \mathrm{Ga}$.

(3) Many cratons inferred not to have formed part of larger amalgamations were characterised by chemical sedimentary platform deposits close to the ArchaeanPalaeoproterozoic boundary (likely related to a peak in global continental crustal growth rates), such as observed for Kaapvaal, São Francisco (prior to ca. $2.5 \mathrm{Ga}$ ), Pilbara, possibly Singhbhum and several others; these deposits are in contrast to cratons within supercontinental constraints, where freeboard appears to have been much higher and such platformal epeiric deposits are absent (e.g., North American cratonic plates, Karelia/Baltica within "Kenorland").

(4) A possible second truly global event (in addition to the BIF-carbonate platform deposits at ca. $2.5 \mathrm{Ga}$ ) may have occurred between ca. 2.45 and $2.2 \mathrm{Ga}$, for which time Condie et al. (2009) postulate a "global magmatic shutdown" which can provide a plausible setting for both the "Great Oxidation Event" and the first global-scale glacial event(s) $(n=3$ ?); this perceived global "event" was possibly tripartite and complex, with inter-relationships as yet imperfectly understood and diachroneity at a lower rank (third- to fourth-order sequences; cf., Catuneanu, 2006) may have been pertinent for both glacial and oxygen-proxy data bases from craton to craton.

(5) At ca. 2.0 Ga a further global event is possible, with pervasive supercontinent assembly finally apparently becoming a reality, and from then on a Phanerozoicstyle plate tectonic regime is accepted by the vast majority of earth scientists, with, however, still highly divergent views as to the chronology of its onset prior to that.

(6) Finally, and possibly of greatest compass, the fragmentary and highly incomplete (accidental?; Miall, 1997) character of the supracrustal record on all cratons must always be borne in mind when analysing chronological variability of any parameter, be it isotopic curves to assess palaeoatmospheric/-oceanic chemical variation, eustatic curves (essentially it would be futile to attempt construction of global sea-level curves for the Precambrian or any part thereof), supercontinental cycles and even accommodation charts, as presented as the core of this thematic paper set.

As a final comment, we dedicate this collection of papers to Wulf Mueller (one of the editors-in-chief of the journal Precambrian Research and master elucidator of Archaean sedimentary-volcanic sequences) who passed away far too soon, in 2010. We also acknowledge the support of the editorial staff of Marine and Petroleum Geology at Elsevier, and the contribution of Wlady Altermann (who guest-edited one paper) as well 
as the reviewers who helped constrain the data and thoughts presented in this collection; the latter are acknowledged in each individual paper.

\section{References}

Ager, D.V., 1981. The Nature of the Stratigraphical Record. MacMillan, Oxford, U.K., p. 122.

Aspler, L.B., Chiarenzelli, J.R., 1998. Protracted breakup of Kenorland, a Neoarchean supercontinent? Geochronologic, tectonostratigraphic and sedimentologic evidence from the Paleoproterozoic. Sedimentary Geology 120, 75-104.

Bleeker, W., 2003. The late Archean record: a puzzle in ca. 35 pieces. Lithos 71, 99-134.

Catuneanu, O., 2006. Principles of Sequence Stratigraphy. Elsevier, Amsterdam, p. 375.

Catuneanu, O., Wopfner, H., Eriksson, P.G., Cairncross, B., Rubidge, B.S., Smith, R.M.H., Hancox, P.J., 2005. The Karoo basins of south-central Africa. Journal of African Earth Sciences 43 (1-3), 211-253.

Catuneanu, O., Abreu, V., Bhattacharya, J.P., Blum, M.D., Dalrymple, R.W., Eriksson, P.G., Fielding, C.R., Fisher, W.L., Galloway, W.E., Gibling, M.R., Giles, K.A., Holbrook, J.M., Jordan, R., Kendall, C.G.St.C., Macurda, B., Martinsen, O.J., Miall, A.D., Neal, J.E., Nummedal, D., Pomar, L., Posamentier, H.W., Pratt, B.R., Sarg, J.F., Shanley, K.W., Steel, R.J., Strasser, A., Tucker, M.E., Winker, C., 2009. Towards the standardization of sequence stratigraphy. Earth-Science Reviews 92, 1-33.

Césari, S.N., Limarino, C.O., Gulbranson, E.L., 2011. An Upper Paleozoic biochronostratigraphic scheme for the western margin of Gondwana. Earth-Science Reviews 106, 149-160.

Cheney, E.S., 1996. Sequence stratigraphy and plate tectonic significance of the Transvaal succession of southern Africa and its equivalent in Western Australia. Precambrian Research 79, 3-24.

Cloud, P.E., 1968. Atmospheric and hydrospheric evolution on the primitive earth. Science 160, 729-736.

Cloud, P.E., 1973. Paleoecological significance of banded iron-formation. Economic Geology 68, 1135-1143.

Condie, C.K., O’Neill, C., Aster, R., 2009. Evidence and implications for a widespread magmatic shutdown for 250 My on Earth. Earth and Planetary Science Letters 282, 294298. 
Crowley, K.D., 1984. Filtering of depositional events and the completeness of sedimentary sequences. Journal of Sedimentary Petrology 54, 127-136.

De Kock, M.O., Evans, D.A.D., Beukes, N.J., 2009. Validating the existence of Vaalbara in the Neoarchean. Precambrian Research 174, 145-154.

De Wit, M.J., 1998. On Archean granites, greenstones, cratons and tectonics: does the evidence demand a verdict? Precambrian Research 91, 181-226.

De Wit, M.J., Hynes, A., 1995. The onset of interaction between the hydrosphere and oceanic crust, and the origin of the first continental lithosphere. In: Coward, M.P., Ries, A.C., (Eds.), Early Precambrian Processes. Special Publications of the Geological Society, London 95, pp. 1-9.

De Wit, M.J., Ashwal, L.D. (Eds.), 1997. Greenstone Belts. Oxford Science Publications, Oxford, U.K., p. 809.

De Wit, M.J., Roering, C., Hart, R.J., Armstrong, R.A., de Ronde, C.E.J., Green, R.W.E., Tredoux, M., Peberdy, E., Hart, R.A., 1992. Formation of an Archaean continent. Nature 357, 553-562.

Donaldson, J.A., Eriksson, P.G., Altermann, W., 2002. Actualistic versus non-actualistic conditions in the Precambrian: a reappraisal of an enduring discussion. In: Altermann, W., Corcoran, P.L. (Eds.), Precambrian Sedimentary Environments: a modern approach to ancient depositional systems. Blackwell, Oxford, U.K., International Association of Sedimentologists Special Publication 33, pp. 3-13.

Eriksson, P.G., Catuneanu, O., 2004. A commentary on Precambrian plate tectonics. In: Eriksson, P.G., Altermann, W., Nelson, D.R., Mueller, W.U., Catuneanu, O. (Eds.), The Precambrian Earth: Tempos and Events. Developments in Precambrian Geology 12, Elsevier, Amsterdam, pp. 201-213.

Eriksson, P.G., Altermann, W., Nelson, D.R., Mueller, W.U., Catuneanu, O. (Eds.), 2004. The Precambrian Earth: tempos and events. Amsterdam, Elsevier, p. 941.

Eriksson, P.G., Banerjee, S., Nelson, D.R., Rigby, M.J., Catuneanu, O., Sarkar, S., Roberts, R.J., Ruban, D., Mtimkulu, M.N., Sunder Raju, P.V., 2009. A Kaapvaal craton debate: Nucleus of an early small supercontinent or affected by an enhanced accretion event? Gondwana Research 15, 354-372.

Eriksson, P.G., Rigby, M.J., Bandopadhyay, P.C., Steenkamp, N.C., 2011. The Kaapvaal craton (South Africa): no evidence for a supercontinental affinity prior to $2.0 \mathrm{Ga}$ ? International Geology Review 53 (11-12), 1312-1330.

Eriksson, P.G., Lenhardt, N., Wright, D.T., Mazumder, R., Bumby, A.J., 2011. Late Neoarchaean-Palaeoproterozoic supracrustal basin-fills of the Kaapvaal craton: 
Relevance of the supercontinent cycle, the "Great Oxidation Event" and "Snowball Earth"? Marine and Petroleum Geology 28, 1385-1401.

Farquhar, J., Namping, W., Canfield, D.E., Oduro, H., 2010. Connections between sulfur cycle evolution, sulfur isotopes, sediments, and base metal sulfide deposits. Economic Geology 105, 509-533.

Frei, R., Gaucher, CA., Poulton, S.W., Canfield, D.E., 2009. Fluctuations in Precambrian atmospheric oxygenation recorded by chromium isotopes. Nature 461, 250-253.

Hamilton, W.B., 1998. Archean magmatism and deformation were not products of plate tectonics. Precambrian Research 91, 143-179.

Hoffman, P.F., 1988. United plates of America, the birth of a craton: Early Proterozoic assembly and growth of Laurentia. Annual Reviews of Earth and Planetary Science 16, 543-603.

Hoffman, P. F., Kaufman, A. J., Halverson, G. P., Schrag, D. P., 1998. A Neoproterozoic Snowball Earth. Science 281, 1342-1346.

Holland, H.D., 1964. On the chemical evolution of the terrestrial and Cytherean atmosphere. In: Brancazio, P.J., Cameron, A.G.W. (Eds.), The Origin and Evolution of Atmospheres and Oceans. John Wiley, Chichester, U.K., pp. 86-97.

Holland, H.D., 1966. Origin and evolution of the atmosphere. McGraw-Hill 1966 Yearbook, Science and Technology, 53-59.

Holland, H.D., 1984. The Chemical Evolution of the Atmosphere and the Oceans. Princeton University Press, Princeton, New Jersey, U.S.A., p. 582.

Holland, H.D., 1994. Early Proterozoic atmospheric change. In: Bengston, S. (Ed.), Early life on Earth. Nobel Symposium No. 84., Columbia Univ. Press, New York, U.S.A., pp. 237-244.

Holland, H.D., 2002. Volcanic gases, black smokers, and the great oxidation event. Geochimica et Cosmochimica Acta 66, 3811-3826.

Holland, H.D., 2009. Why the atmosphere became oxygenated: A proposal. Geochimica et Cosmochimica Acta 73, 5241-5255.

Huston, D.L., Logan, G.A., 2004. Barite, BIFs and bogs: Evidence for the evolution of the Earth's early hydrosphere. Earth and Planetary Science Letters 220, 41-55.

Kasting, J.F., 1987. Theoretical constraints on oxygen and carbon dioxide concentrations in the Precambrian atmosphere. Precambrian Research 34, 205-229. 
Kasting, J.F., 2001. Earth history: The rise of atmospheric oxygen. Science 293, 819-820.

Kasting, J.F., Brown, L.L., 1998. The early atmosphere as a source of biogenic compounds. In: Brack, A. (Ed.), Molecular Origins of Life. Cambridge University Press, Cambridge, U.K., pp. 35-56.

Kasting, J.F., Siefert, J.L., 2002. Life and the evolution of Earth's atmosphere. Science 296, 1066-1068.

Kirschvink, J. L., 1992. Late proterozoic low-latitude global glaciation: The snowball Earth. In: Schopf, J.W., Klein, CA. (Eds.), The Proterozoic Biosphere: a multidisciplinary study. Cambridge University Press, Cambridge, U.K., pp. 51-52.

Leach, D.L., Bradley, D.C.A., Huston, D., Pisarevsky, S.A., Taylor, R.D., Gardoll, S.J., 2010. Sediment-hosted Lead-Zinc deposits in Earth history. Economic Geology 105, 593625.

Meert, J.G., 2002. Paleomagnetic evidence for a Paleo-Mesoproterozoic supercontinent. Gondwana Research 5, 207-215.

Miall, A.D., 1997. The Geology of Stratigraphic Sequences. Springer, Berlin, p. 433.

Ojakangas, R.W., Morey, G.B., Southwick, D.L., 2001. Paleoproterozoic basin development and sedimentation in the Lake Superior region, North America. Sedimentary Geology 141-142, 319-341.

Rogers, J.J.W., 1996. A history of continents in the past three billion years. Journal of Geology 104, 91-107.

Rogers, J.J.W., Santosh, M., 2002. Configuration of Columbia, a Mesoproterozoic supercontinent. Gondwana Research 5, 5-22.

Ruban, D.A., 2007. Amalgamation and destruction of Baltica during the ProterozoicPhanerozoic: a comparative analysis of the continent evolution. In: Glebovitskij, V.A. (Ed.), Aktual'nye problemy geologii dokembrija, geofiziki i geoekologii. SanktPeterburg, IGiGD, pp. 23-25 (in Russian).

Rye, R., Holland, H.D., 1998. Paleosols and the evolution of atmospheric oxygen: a critical review. American Journal of Science 298, 621-672.

Stanistreet, I.G., 1993. Ancient and modern examples of tectonic escape basins: the Archaean Witwatersrand Basin compared with the Cenozoic Maracaibo Basin. In: Frostick, L.E., Steel, R.J. (Eds.), Tectonic Controls and Signatures in Sedimentary Successions. International Association of Sedimentologists Special Publication 20, Blackwell, Oxford, pp. 363-376. 
Trendall, A.F., 2002. The significance of iron-formation in the Precambrian stratigraphic record. In: Altermann, W., Corcoran, P.L. (Eds.), Precambrian Sedimentary Environments: a modern approach to ancient depositional systems. Blackwell, Oxford, U.K., pp. 33-66.

Unrug, R., 1992. Supercontinent cycle and Gondwana assembly: component cratons and timing of suturing events. Journal of Geodynamics 12, 703-714.

Voegelin, A.R., Nägler, T.F., Beukes, N.J. Lacassie, J.P., 2010. Molybdenum isotopes in late Archean carbonate rocks: Implications for early Earth oxygenation. Precambrian Research 182, 70-82.

Walker, J.CA.G., 1977. Evolution of the Atmosphere. Macmillian, New York, U.S.A., p. 318.

Walker, J.CA.G., Klein, CA., Sachidlowski, M., Schopf, J.W., Stevenson, D.J., Walter, M.R., 1983. Environmental evolution of the Archean-Early Proterozoic Earth. In: Schopf, J.W. (Ed.), Earth's Earliest Biosphere - its Origin and Evolution. Princeton University Press, Princeton, New Jersey, U.S.A., pp. 260-290.

Williams, G.E., 2004. The paradox of Proterozoic glaciomarine deposition, open seas and strong seasonality near the Palaeo-Equator: global implications. In: Eriksson, P.G., Altermann, W., Nelson, D.R., Mueller, W.U., Catuneanu, O. (Eds.), The Precambrian Earth: tempos and events. Elsevier, Amsterdam, pp. 448-459.

Williams, H., Hoffman, P.F., Lewry, J.F., Monger, J.W.H., Rivers, T., 1991. Anatomy of North America: thematic portrayals of the continent. Tectonophysics 187, 117-134.

Young, G.M., 2004. Earth's two great Precambrian glaciations: aftermath of the "Snowball Earth" hypothesis. In: Eriksson, P.G., Altermann, W., Nelson, D.R., Mueller, W.U., Catuneanu, O. (Eds.), The Precambrian Earth: tempos and events. Elsevier, Amsterdam, pp. 440-448. 